\title{
OPTIMALISASI LINGKUNGAN SEKITAR SEBAGAI SUMBER BELAJAR ANAK USIA DINI DI DESA TAWAR KECAMATAN GONDANG KABUPATEN MOJOKERTO
}

\author{
Isabella Hasiana'), Aulia Insani' ${ }^{2)}$, Aisyah ${ }^{3)}$, Ahmad Fachrurrazi ${ }^{4)}$ \\ 1,2,3,4 Fakultas Keguruan dan Ilmu Pendidikan, Universitas PGRI Adi Buana Surabaya \\ Email: ${ }^{1}$ isabella@unipasby.ac.id, ${ }^{2}$ aulia291@unipasby.ac.id, ${ }^{3}$ aisyah@unipasby.ac.id, \\ 4fachrurrazi@unipasby.ac.id
}

\begin{abstract}
Abstrak
Anak usia dini merupakan individu dengan usia 0-6 tahun yang sedang berkembang. Dimana dalam perkembangannya tersebut tentu ia membutuhkan stimulasi. Pemberian stimulus yang tepat tentu akan mengembangkan dan mengoptimalkan aspek perkembangan anak sehingga potensi anak untuk tumbuh kembangnya semakin pesat. Potensi pada anak yang perlu dikembangkan mencakup seluruh aspek perkembangan kemampuan dasar anak, yaitu aspek fisik motorik, kognitif, bahasa, sosial emosi, seni serta moral dan agama. Oleh sebab itu, pemberian stimulus tidak hanya didapatkan dari alat permainan edukatif yang ada di pasaran, melainkan bisa dengan menggunakan bahanbahan yang ada dilingkungan sekitar. Banyak hal yang bisa ditemukan dengan memanfaatkan lingkungan sekitar sebagai sumber belajar anak. Tidak hanya penekanan dari segi ekonomi, melainkan semakin mendekatkan hubungan antara anak dengan orangtua dan menanamkan kepada anak sejak dini rasa cinta kepada lingkungan. Capaian hasil dari pengabdian pada masyarakat ini yaitu mereka memiliki pengetahuan tentang penggunaan bahan-bahan yang ada di lingkungan sekitar dan dapat mengoptimalkan dengan baik sebagai sumber belajar pada anak usia dini.
\end{abstract}

Kata Kunci: Lingkungan, Anak, Sumber Belajar, Optimalisasi

\begin{abstract}
Early childhood is a developing individual. Where in its development certainly he needs stimulation. Giving the right stimulus will certainly develop and optimize aspects of child development so that the child's potential for growth and development is growing rapidly. Potentials in children that need to be developed include all aspects of children's basic abilities, namely physical aspects of motor, cognitive, language, social emotion, art and moral and religion. Therefore, giving stimulus is not only obtained from educational toys on the market, but can be done by using materials in the surrounding environment. Many things can be found by utilizing the surrounding environment as a source of children's learning. Not only the emphasis in terms of economics, but the closer relationship between children and parents and instill in children from an early love for the environment. The achievement of community service is that they have knowledge about the use of materials in the surrounding environment and can optimize it well as a source of learning in early childhood.
\end{abstract}

Keyword: Environment, Child, Learning Resources, Optimization

\section{PENDAHULUAN}

Media merupakan sumber belajar yang dijadikan perantara oleh guru agar membantu pelaksanaan kegiatan belajar. Namun terkadang ada kendala yang dihadapi oleh sekolah dalam pembuatan media tersebut.
Berdasarkan analisis situasi terhadap kondisi yang didapatkan dari sekolah bahwa orangtua dan guru mengalami kesulitan dalam menggunakan maupun membuat media pembelajaran karena ketersediaan bahan yang kurang mencukupi sehingga guru menggunakan bahan seadanya saja. 
Tidak hanya dari pihak sekolah, orangtua juga mengalami kesulitan untuk mengembangkan potensi yang dimiliki anak. Orangtua yang sibuk untuk bekerja, tingkat pendidikan orangtua yang menganggap bahwa pendidikan itu yang utama adalah anak bisa membaca, menulis dan berhitung dan dilakukan dengan cara yang konvensional.

Lingkungan merupakan sumber belajar untuk anak yang memberikan kesempatan belajar dan mendapatkan pengetahuan secara langsung dari lingkungan.

Kegiatan belajar mngajar tidak dapat dipisahkan dengan sumber belajar. Adanya sumber belajar tentu membantu anak dalam memahami suatu pengetahuan yang tidak hanya didapatkan dari buku literatur yang ada.

Potensi pada anak yang perlu distimulasi tentunya semuah aspek perkembangan kemampuan dasar, yakni aspek perkembangan fisik motorik, kognitif, sosio dan emosional, bahasa, seni serta nilai agama dan moral.

Berbagai upaya yang dilakukan oleh guru dan orangtua untuk memberikan stimulasi terhadap anak dalam mengembangkan aspek perkembangan. Salah satunya adalah tersedianya media dan sumber belajar yang dapat menstimulasi aspek perkembangan.

Stimulasi adalah suatu pemberian rangsangan pada anak dengan menggunakan latihan, belajar, trasnfer ilmu atau yang lainnya dengan tujuan agar individu mampu melakukan suatu keterampilan atau kemampuan yang ingin ditingkatkan (Hapsari, 2016). Pemberian stimulasi sangat penting bagi anak sejak usia dini sehingga dapat berkembang dengan optimal dalam berbagai aspek perkembangan. Tentu saja pemberian stimulasi tetap diberikan sesuai dengan tahapan usia perkembangan sehingga anak tidak merasa terbebani.

Berdasarkan informasi yang diberikan kepada tim Pengabdian pada Masyarakat (PPM) PG-PAUD bahwa orang tua dan guru menemukan hambatan atau kendala yang terkait dengan permasalahan kurangnya sumber dan media pembelajaran.

Keterbatasan dalam menunjang proses kegiatan belajar mengajar yang terdapat di sekolah PAUD. Selain itu, bahan penunjang kegiatan belajar di lembaga PAUD seharusnya lengkap, tetapi di lapangan banyak yang tidak terpenuhi. Hal ini dikarenakan keterbatasan sumber bahan alat peraga, serta lembar kerja anak juga terbatas.

Oleh sebab itu, pendidik juga inovasi, kreatif serta mengeksplorsi dalam pembuatan media sebagai sumber belajar anak. Dengan memiliki inovas dan kreatifitas yang tinggi dalam menggunakan bahan yang ada di alam sekitar maka akan membantu proses belajar mengajar.

Tidak hanya guru yang berperan dalam tumbuh kembang anak. Orangtua juga perlu ada keterlibatan dalam proses tersebut. Oleh sebab itu, kegiatan pengabdian pada masyarakat yang menjadi sasaran adalah orangtua yang memiliki anak usia dini, serta guru PAUD agar mendapatkan informasi tentang pemanfaatan lingkungabn sekitar dalam mengembangkan aspek perkembangan anak.

\section{KAJIAN LITERATUR}

Lingkungan dapat diartikan sebagai suatu gejala alam yang ada disekitar kita, dimana didalam lingkungan tersebut terdapat interaksi antara faktor biotik (hidup) dan faktor abiotik (tak hidup) dimana lingkungan menyediakan rangsangan (stimulus) terhadap individu dan sebaliknya individu juga memberikan respon terhadap lingkungan (Efendi, 2013).

Selain itu menurut Winarni (2012) lingkungan di sekitar anak dianggap salah satu sumber belajar yang yang dapat dimanfaatkan untuk mencapai suatu hasil belajar yang maksimal dan berkualitas. Tentu saja hal ini juga harus didukung dengan kemampuan pendidik untuk mengolah lingkungan menjadi salah satu sumber belajar yang tepat dan sesuai bagi anak.

Adapun manfaat yang didapatkan dengan menggunakan lingkungan sebagai media sumber belajar anak, yaitu: (1). Memberikan pengalaman belajar yang lebih konkrit dan nyata bagi anak sehingga membuat hasil belajar menjadi lebih bermakna; (2). Pemanfaatan sumber belajar dapat mengatasi keterbatasan dalam ruang dan waktu dan daya indera. Sebagai contoh, seorang guru ingin menerangkan tentang bencana alam banjir, maka ia dapat menggunakan video tentang banjir; (3). Menambah wawasan dan pengalaman anak. Misalnya, guru ingin menerangkan tentang 
hewan yang ada di air. Maka ia dapat menggunakan sumber belajar lain yaitu akuarium sehingga anak dapat mengamati hewan yang ada dalam akuarium tersebut; (4). Meningkatkan motivasi belajar anak. Dalam hal ini anak akan diberikan sumber pengetahuan, sumber informasi dan sumber belajar yang berbeda sehingga anak semakin termotivasi atau bersemangat untuk selalu belajar dan mendapatkan pengetahuan yang baru; (5). Mengembangkan kemampuan berpikir anak untuk lebih kritis dan positif. Maksudnya ialah dengan diberikan berbagai alternatif sumber belajar maka akan mengasah kemampuan anak dalam berpikir kritis. Misalnya, anak diajak untuk pergi ke kebun binantang, maka dari apa yang ia lihat, ia dengar dan rasakan akan muncul berbagai pertanyaan yang terus mengasah kemampuan berpikirnya

(http://windatepe.blogspot.com/2012/12/pema nfaatan-lingkungan-sebagai-sumber.html).

Penelitian membuktikan bahwa jika anak belajar dari lingkungan akan semakin mengasah kemampuan berpikirnya dan membuat anak menjadi peka terhadap hal yang terjadi di sekitarnya serta semakin tumbuh kecintaannya terhadap lingkungan. Senada dengan yang disampaikan oleh Morrison (2012), bahwa lingkungan membantu anak untuk dapat belajar lebih baik karena langsung berinteraksi dengan alam.

\section{METODE PELAKSANAAN}

Metode pelaksanaan melalui beberapa tahapan, yaitu: (1). Melakukan analisis situasi terhadap kondisi yang ada di lapangan; (2). Menggali informasi yang mendalam melalui wawancara dan angket yang diberikan kepada orangtua yang memiliki anak usia dini (0-6 tahun), serta juga dilakukan kepada pendidik PAUD yang ada di sekitar Desa Tawar; (3). Melakukan kegiatan pengabdian masyarakat dengan menggunakan metode ceramah yang diikuti oleh 25 orangtua.

\section{HASIL DAN PEMBAHASAN}

Tim Pengabdian berupaya mengeksplorasi kondisi lingkungan Desa Tawar Kabupaten Mojokerto melalui observasi langsung dan wawancara. Dalam pengamatan, saran dan prasarana belajar baik di rumah maupun sekolah sangat sederhana.
Salah satu lembaga PAUD yang ada di desa Tawar memiliki tempat bermain yang cukup luas, namun jumlah permainan outdoor yang ada terbatas. Antara lain hanya ada ayunan, jungkat-jungkit dan papan titian.

Berbeda kondisi dengan yang ada di rumah, dimana orang tua berasumsi bahwa anaknya sudah puas dengan sarana dan prasarana di sekolah, sehingga ada beberapa orang tua yang tidak memberikan sarana bermain yang bisa merangsang perkembangan anak.

Pendapat orang tua, ketika dilakukan wawancara, mereka mengatakan alasan untuk tidak memberikan alat permainan kepada anak di rumah karena faktor keuangan. Orangtua yang sibuk bekerja, sehingga kurang memiliki waktu luang yang cukup banyak untuk membantu dalam memberikan stimulasi pada anak. Pada dasarnya, ada manfaat yang dapat dirasakan anak saat orangtua terlibat dalam pendidikan anak, yaitu (1). Dapat meningkatkan kepercayaan diri anak. Anak tumbuh dan berkembang menjadi pribadi yang memiliki rasa percaya diri yang tinggi, mampu menyelesaikan masalah; (2). Meningkatkan keinginan anak untuk sekolah. Jika orangtua terlibat aktif dalam pendidikan anak, maka hasrat anak untuk terus bersekolah akan sangat tinggi. Meskipun rata-rata penduduk hanya mengenyam pendidikan sampai tingkat sekolah dasar, namun setidaknya anak mereka dapat mengenyam pendidikan minimal tingkat SMA; (3). Meningkatkan perilaku positif anak. Hal ini akan meminimalisir perilaku negatif anak, misalnya suka bicara kasar, suka membolos sekolah, dan sebagainya;(4). Meningkatkan pencapaian perkembangan anak. Orangtua yang terlibat dalam pendidikan anak, dan menerapkan pola asuh yang tepat akan membuat anak memiliki perkembangan yang optimal.

Keterlibatan orangtua dalam pendidikan anak tidak hanya dirasakan oleh anak itu sendiri, namun dari segi orangtua juga merasakan manfaatnya, yaitu: (1). Meningkatkan harapan orangtua pada anak, (2). Meningkatkan keinginan orangtua untuk terus belajar; (3). Meningkatkan kerjasama orangtua dengan sekolah.

Manfaat juga dirasakan oleh pihak sekolah, antara lain, (1). Mendukung iklim sekolah yang lebih baik; (2). Mendukung 
kemajuan sekolah secara keseluruhan;

Meningkatkan semangat kerja guru.

Oleh sebab itu, orang tua sangat mengharapkan dilakukan perbaikan dalam sarana prasarana sumber belajar agar kualitas tetap meningkat.

Senada dengan pemanfaatan lingkungan sebagai bahan belajar. Tim pengabdian memberikan solusi dalam kegiatan parenting untuk menginformasikan bahwa apa yang ada dilingkungan dapat dijadikan sumber belajar guna menstimulasi aspek perkembangan anak baik di rumah maupun di sekolah. Misalnya, kardus bekas bisa dijadikan media, roti tawar dibentuk dijadikan alat bermain kognitif seperti berhitung, mengecap dengan wotel, batang sawi dll, serta botol air mineral dan masih banyak lagi bahan yang mudah didapatkan di lingkungan sekitar yang dapat di jadikan sumber belajar.

Fasilitas sumber belajar yang terbatas bukan halangan untuk melaksanakan proses pembelajaran baik di rumah maupun sekolah. Seperti yang dikemukakan oleh Semiawan (1989) bahwa kita seringkali melupakan lingkungan sekitar yang memiliki banyak manfaat yang dapat dijadikan sumber belajar, contohnya, masyarakat, lingkungan sekitar, serta peristiwa yang terjadi yang mampu menarik perhatian anak.

Senada dengan Pasya (2008) menjelaskan bahwa lingkungan merupakan kesatuan ruang dengan semua benda, kekuatan makhluk hidup termasuk manusia dan seluruh tingkah laku yang menentukan nkehidupan dan kesejahteran manusia dan makhluk hidup lainnya.

Lingkungan belajar yang baik adalah lingkungan yang sesuai dengan proses belajar dan tujuan pembelajaran sehingga dapat menstimulasi aspek perkembangan anak. Hal ini dapat diperoleh di lingkungan rumah maupun sekolah.

Optimalisasi dalam pemanfaatan lingkungan sebagai sumber belajar diperlukan agar pembelajaran di rumah dan sekolah lebih variasi sehingga anak mendapatkan pengalaman belajar secara langsung dan riil, karena dengan seperti itu anak merangsang daya tangkap dan daya pikir dengan baik sehingga diharapkan kelak mereka mampu menerapkan pengalaman belajar yang di dapat saat usia dini dapat diterapkan di masa depan karena sejak dini sudah diajarkan untuk berinteraksi dengan lingkungan. Interaksi manusia dengan lingkungan merupakan proses belajar yang terjadi secara terus menerus.

Suatu keterbatasan bukan lah suatu halangan, lingkungan sekitar memiliki potensi dan dapat dimanfaatkan sebagai salah satu sumber belajar. Dengan ini cara meminimnalisir keterbatasan alat permaianan para orang tua dan guru bisa memanfaatkan barang bekas, sawah, kebun, akuarium, pabrik atau bahkan daun-daun atau bonggol jagung hasil pertanian yang dapat dijadikan alat permainan.

Orang tua dan guru sebaiknya bekerja sama untuk mengembangkan potensi anakanak dengan pemanfaatan lingkungan sehingga belajar yang berkualitas terwujud, sehingga dengan begitu orang tua dan guru membantu pemerintah untuk menghasilkan generasi yang mampu bersaing secara sportif dengan bangsa lain serta menjadikan anak selalu cinta dan bangga menjadi anak Indonesia karena memiliki lingkungan yang kondusif untuk dijadikan sumber belajar.

\section{KESIMPULAN}

Kondisi lingkungan Desa Tawar Kecamatan Gondang Kabupaten Mojokerto, pada dasrnya tidak jauh berbeda dengan kondisi lingkungan di desa atau kota lain. Desa tawar sebenarnya bukan desa terpencil melainkan desa yang semi kota. Masyarakatnya bermata pencahariannya sebagai petani, pedagang, guru dan lain sebagainya, dengan kondisi tersebut lingkungan desa tawar dapat dimanfaatkan sebagai sumber belajar untuk anak.

Sementara, kondisi sekolah dengan sarana dan prasarana belajar yang sederhana, memiliki tempat bermain cukup luas akan tetapi peralatan permainan masih sangat terbatas hanya ada ayunan, papan titian dan jungkat-jungkit. Kondisi tersebut tidak menurunkan semangat para guru membuat alat peraga sebagai sumber belajar.

Orang tua dan guru memanfaatkan bahan yang ada dilingkungan seperti daun yang gugur, bonggol jagung, serta kardus bekas yang dapat dijadikan sebagai alat permainan edukatif. Selain itu orang tua dan guru juga dapat memanfaatkan sawah, 
kandang hewan ternak, toko, dan lapangan sebagai sumber belajar.

Berdasarkan hal tersebut, hasil yang dicapai anak mampu memahami pentingnya lingkungan, serta memiliki pengetahuan tentang manfaat segala seuatu yang ada di Desa Tawar Kecamatan Gondang Kabupaten Mojokerto. Daya pikir, daya tangkap dan daya konsentrasi anak semakin meningkat karena mereka belajar langsung dengan lingkungannya. Serta dengan memanfaatkan lingkungan sebagai sumber belajar anak juga diharapkan untuk cinta dengan lingkunganya.

Dari hasil parenting yang dilakukan, juga dibagikan brosur untuk mengingatkan orangtua pentingnya terlibat dalam pendidikan anak dan memanfaatkan lingkungan yang ada disekitar sebagai sumber belajar anak. Agar tumbuh kembang anak dapat berkembang dengan optimal.
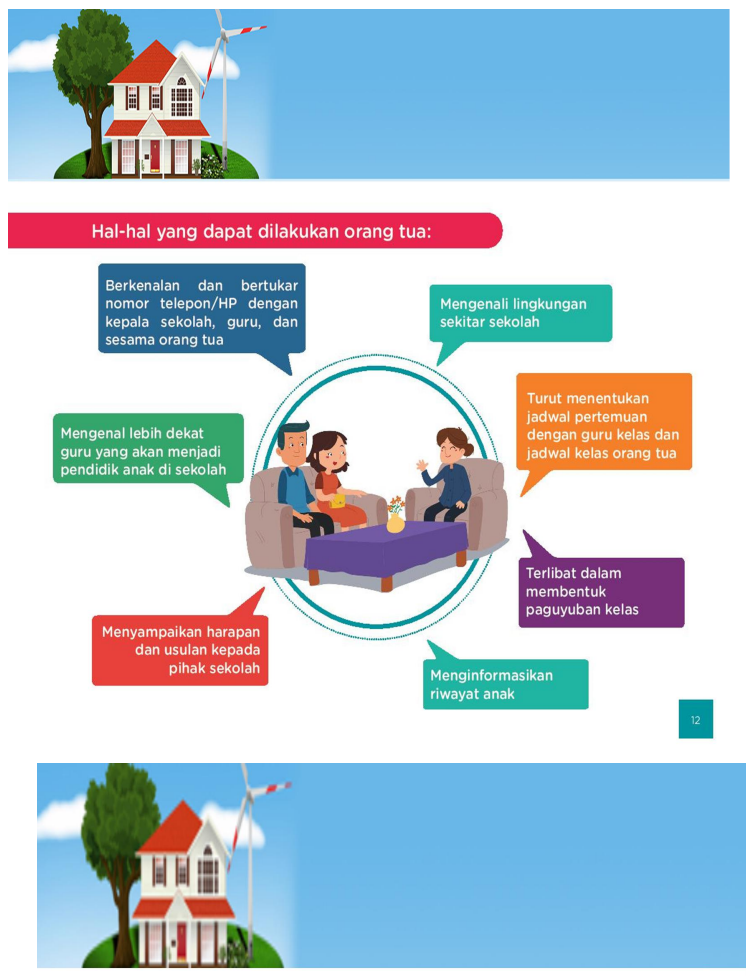

A Pembiasaan di Keluarga
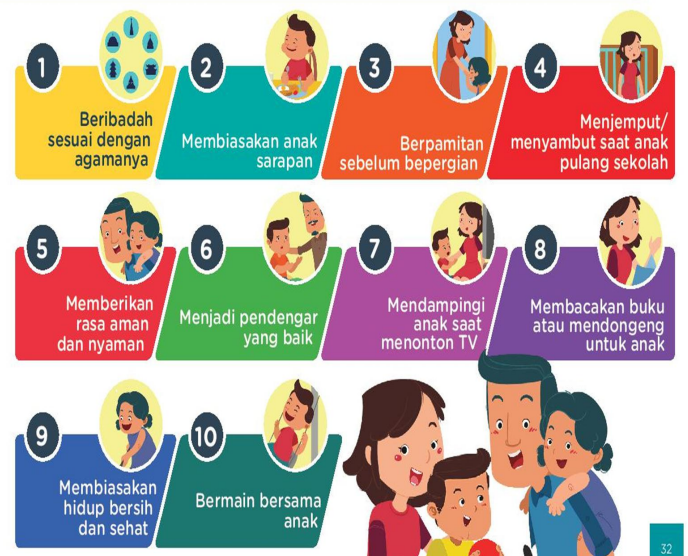

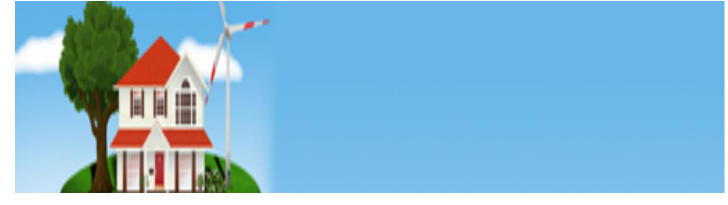

B Menciptakan Lingkungan yang Aman, Nyaman, dan Menyenangkan

Rumah yang dihuni oleh keluarga harus menjadi tempat yang aman, nyaman dan menyenangkan bagi seluruh anggota keluarga. Rumahku adalah surgaku.

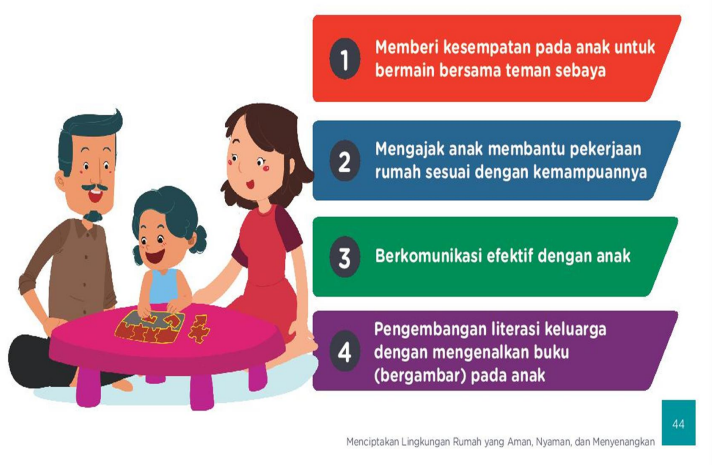

\section{REFERENSI}

Efendi. 2013. Lingkungan Sebagai Media Pembelajaran. Di unduh di http://efendi08.blogspot.co.id/2013/0 3/lingkungan-sebagaimediapembelajaran.html

Hapsari. 2016. Psikologi Perkembangan Anak. Indeks.

Morrison. 2012. Dasar-Dasar Pendidikan Anak Usia Dini (PAUD). Indeks.

Pasya. 2008. Lingkungan sebagai Sumber Belajar.http:file.upi.edu/Direktori/FPIP S/jur.geografi/196103231986031 gurni wanka milpasya/lnk-ajar.pdf.

Semiawan, 1989. Pendekatan Keterampilan Proses: Bagaimana Mengaktifkan Siswa Dalam Belajar. Jakarta: Gramedia.

Winarni. 2012. Lingkungan sebagai Sumber Belajar. Di unduh di http://diarywiens.blogspot.co.id/201 2/09/lingkungan-sebagaisumberbelajar $11 . \mathrm{html}$

http://windatepe.blogspot.com/2012/12/pema nfaatan-lingkungan-sebagai sumber.html 
ABADIMAS ADI BUANA

e-ISSN 2622-5719, p-ISSN 2622-5700

VOL. 04. NO. 1, 1 Juli 2020 